\title{
Lichen planus pigmentosus-inversus with lesions on labia majora in an Indian lady
}

\author{
Ashok Ghorpade \\ Director in-charge and Head, Department of Dermatology and Venereology, J.L.N Hospital and Research Centre, India
}

\begin{abstract}
Lichen planus pigmentosus-inversus in an old Indian lady involving labia majora along with skin lesions mostly in flexures is reported. The diagnosis suggested by the history and clinical features, was confirmed by histopathology. This condition has been infrequently reported and the prominent lesions on labia majora have not been mentioned earlier.
\end{abstract}

\section{Case report}

A 70-year-old Indian lady presented with multiple, asymptomatic skin lesions on external genitalia, inguinal regions, neck and chest since last 4 years. Cutaneous examination showed multiple well-defined, brownish, discrete and coalescing macules and patches having irregular borders on both the both the labia majora (interspersed here with violaceous lesions), both inguinal regions, anterior aspect of neck, right infra and inter-mammary area (Figures 1 and 2). She had no history of preceding raised, itchy skin lesions at the sites of the brownish macules. There was no history of topical or oral medication or systemic problem. Nail, scalp, mucosae and systemic examination and routine hematology, liver and kidney function tests were normal. Serological tests for hepatitis B and C viruses were negative. Skin biopsy from a brownish, macular skin lesion from right inframmammary region revealed a thinned epidermis with basal cell degeneration, melanin incontinence and mild, scattered chronic inflammatory infiltrate in upper and mid-dermis. No saw tooth appearance of rete pegs was seen (Figure 3). There was no relief after using a combination of mometasone furoate $0.1 \%$ and tretinoin $0.025 \%$ cream once daily for 7 months.

\section{Discussion}

Lichen Planus Pigmentosus (LPP), a chronic infrequently reported variant of lichen planus is characterized by dark brown, usually asymptomatic, hyperpigmented patches in sun exposed areas and flexures [1]. In an Indian study, axillary involvement in LPP was seen in $8.9 \%$, inframammary lesions in $6.5 \%$, while groin was found to be involved in 3.2\% of the 124 reported cases [2]. Vega et al. [3] found LPP lesions mainly on the face and trunk, while axillae and inguinal regions were affected in only two cases.

The term LPP-inversus, was coined in 2001 by Pock et al. [4] for a condition observed in seven patients having skin lesions similar to LPP, but with predominant distribution in the flexures and not on the sun exposed sites. The involved areas include axillae, groin, inframammary and submammary regions, popliteal and antecubital fossae, flexor aspect of neck, shins and back. The brown macules were mostly intertriginous, while those lesions outside these areas if present, had the appearance of ordinary lichen planus. Out of the 20 reports of this rare variant of LPP published so far, 12 have been in females and 8 in males with duration varying between 2 months to 15 years. It is commoner after the middle age with 15 cases occurring above 50 years of age, the oldest report being in an 84-year-old male. The commonest sites reportedly involved have been the axillae and the groin in 17 and 14 patients respectively. Involvement of inframammary regions and neck was described in 4 and 2 patients previously. The mucosae, scalp and nails were spared. The histopathology revealed marked melanin incontinence and hydropic degeneration of the basal cells in 17 and 11 of the 20 case reports, respectively. There was intense lichenoid eruption in 10 and scanty inflammatory infiltrate in 7 cases [4-12]. Pock, et al. [4] opined that the lichenoid reaction in this condition occurs in a very short time with marked hydropic degeneration of the basal layer, giving hardly any time for the compensatory keratinocytic proliferation, as seen in classical LP, transforming the livid papular lesions into brownish macules having a regressive lichenoid reaction with intense pigmentary incontinence. The differentiation from ashy dermatosis and pigmented contact dermatitis is by the history, clinical features, distribution of the lesions and histopathology. The response to treatment is variable. Munoz-Perez et al. [7] observed mild improvement after two months of oral deflazacort, while Kim, et al. [10] reported resistance to topical tacrolimus and clobetasol propionate ointment. Kashima et al. [11] reported spontaneous remission within 6 months and Ohshima et al. [12] found that prolonged topical application of mometasone furoate ointment for about 9 months was required for achieving effective results.

Correspondence to: Dr. Ashok Ghorpade, A4/3, Green betel residency, Deepak Nagar Durg, Chhattisgarh, India-491001, Tel: 0091788 2970003; Fax: 0091788 2241926; E-mail: draghorpade@yahoo.com

Key words: lichen planus pigmentosus, lichen planus pigmentosus-inversus, lichen planus; labia majora

Received: August 20, 2015; Accepted: September 28, 2015; Published: November 02, 2015 


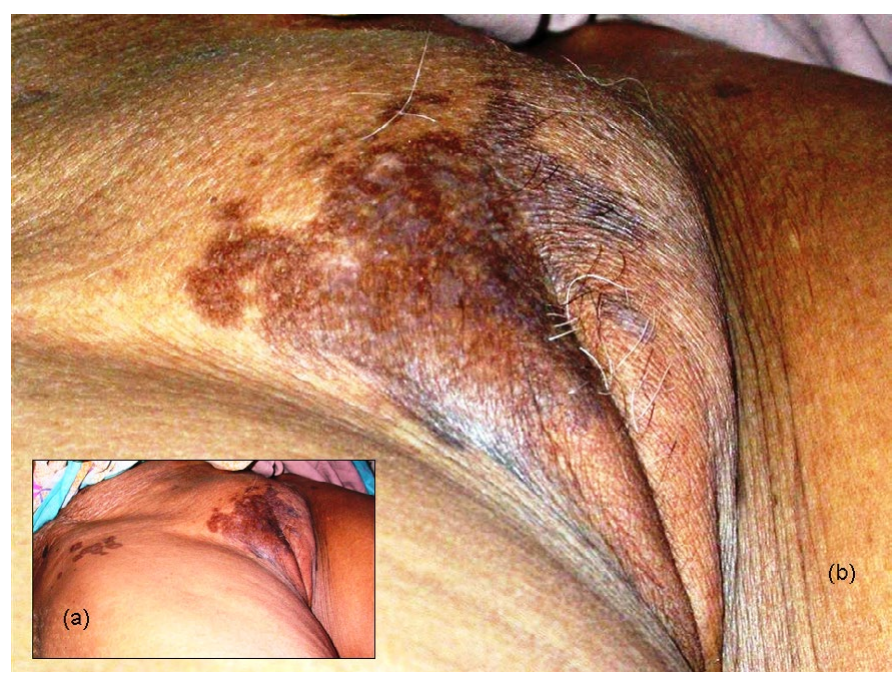

Figure 1. a) Well defined brownish patches on both labia majora (with patchy violaceous lesions) and both the inguinal folds. b) Close up of labial lesions with violaceous lesions in between (more on right side).

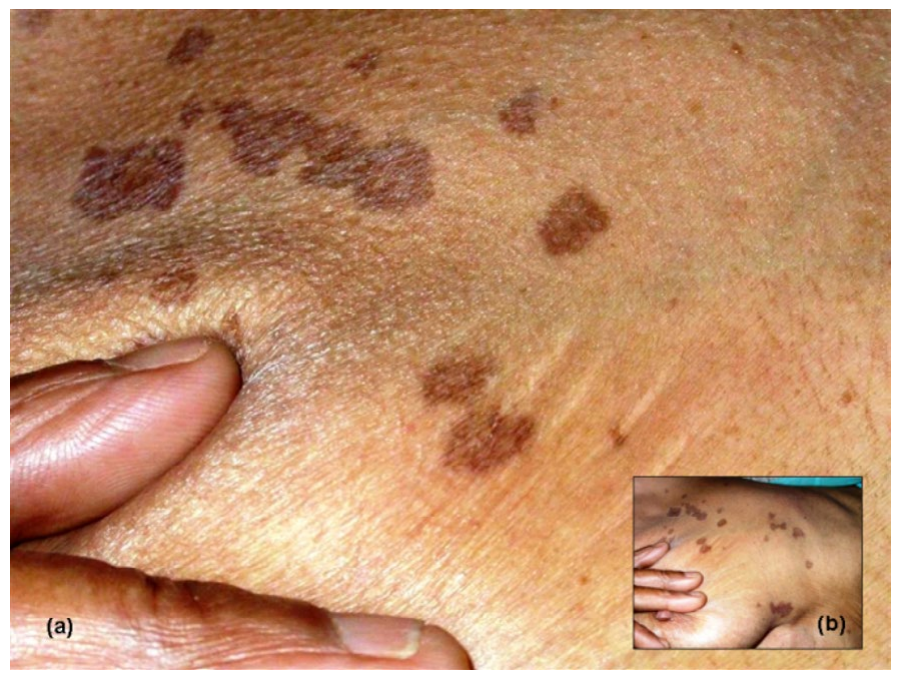

Figure 2. a) Close-up of brownish well defined patches in intermammary region, b) Inset showing the location of lesions in the intermammary and submammary region.

The diagnosis here was based on history of asymptomatic, brownish macules lesions without a history of, pre-existing itchy, papular skin lesions, cutaneous findings of brownish patches and their distribution over the flexures and histopathology. The older age of onset and failure of response to steroid and tretinoin cream also favored LPP instead of LP. The presence of violaceous lesions patches interspersed between the brownish patches on labia majora and the sparing of axillae were the unusual features. Whether this co-existence of violaceous and pigmented patches points towards the suggests morphogenesis of LPP from LP as suggested reported earlier [4], is a moot point. Kashima et al. [11] found CD $8^{+} \mathrm{T}$-lymphocytes with damage to keratinocytes suggesting cytotoxic damage to keratinocytes in two Japanese cases. The keratinocytes expressed focal and weak HLA-DR immunoreactions, partly accounting for the weaker inflammatory response and mild pruritus. They opined that in addition to cytotoxic cell injury,

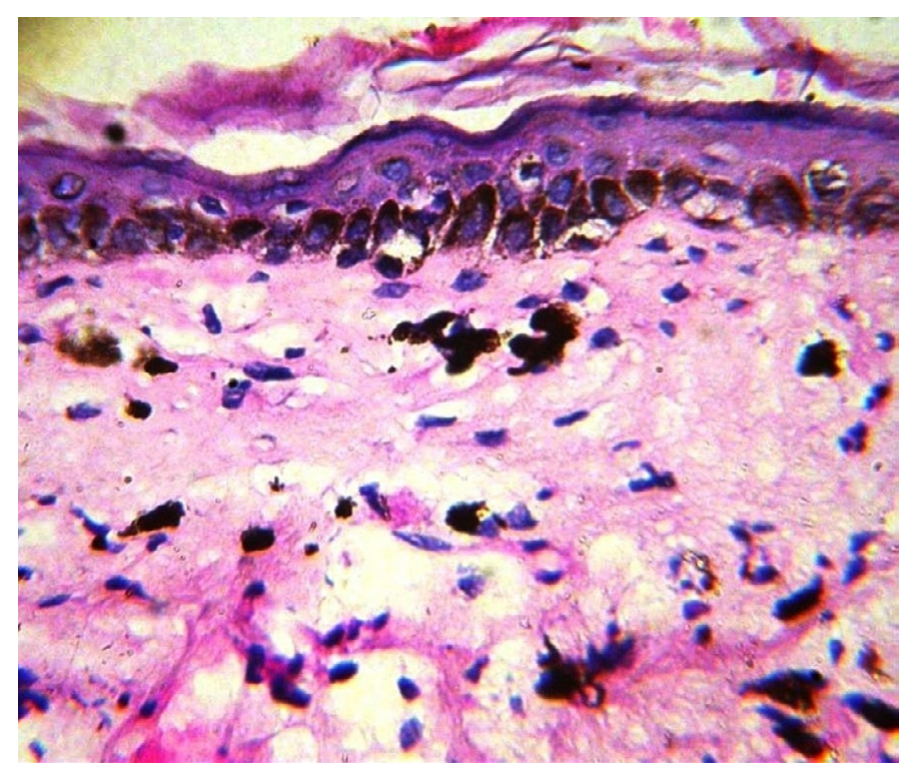

Figure 3. Histopathology from skin lesions showing mild hyperkeratosis, marked epidermal thinning with mild basal cell degeneration, pigment incontinence in upper dermis and scanty chronic inflammatory infiltrate (Haematoxylin and eosin; original magnification $\mathrm{x} 100)$.

Langerhans cell-mediated immune response could play an important role in pathogenesis of LPP-inversus. Ohshima et al. [12] proposed that stimulation of sweat, moist environment and/ or other external factors including friction (aggravation of lesions after occlusion with a polyurethane film), may have an etiological role by evoking koebner's phenomenon like in lichen planus.

The prominent involvement of labia majora, that too with violaceous lesions seen in the present case has not been reported earlier. Though LPP-pigmentosus was first reported from India [1], the inversus variety has not been reported till date from our country. Creating awareness might help in bringing out some more cases of this probably under-reported condition.

\section{References}

1. Bhutani LK, Bedi TR, Pandhi RK, Nayak NC (1974) Lichen planus pigmentosus. Dermatologica 149: 43-50. [Crossref]

2. Kanwar AJ, Dogra S, Handa S, Parsad D, Radotra BD (2003) A study of 124 Indian patients with lichen planus pigmentosus. Clin Exp Dermatol 28: 481-485. [Crossref]

3. Vega ME, Waxtein L, Arenas R, Hojyo T, Dominguez-Soto L (1992) Ashy dermatosis and lichen planus pigmentosus: a clinicopathologic study of 31 cases. Int $J$ Dermatol 31: 90-94. [Crossref]

4. Pock L, Jelínková L, Drlík L, Abrhámová S, Vojtechovská S, et al. (2001) Lichen planus pigmentosus-inversus. J Eur Acad Dermatol Venereol 15: 452-454. [Crossref]

5. Gaertner E, Elstein W (2012) Lichen planus pigmentosus-inversus: case report and review of an unusual entity. Dermatol Online J 18: 11. [Crossref]

6. Jung YJ, Lee YH, Lee SY, Lee WS (2011) A Case of Lichen Planus Pigmentosusinversus in a Korean Patient. Ann Dermatol 23: 61-63. [Crossref]

7. Muñoz-Pérez MA, Camacho F (2002) Pigmented and reticulated plaques of folds. A case of lichen planus pigmentosus-inversus? Eur J Dermatol 12: 282. [Crossref]

8. Bennàssar A, Mas A, Julià M, Iranzo P, Ferrando J (2009) Annular plaques in the skin folds: 4 cases of lichen planus pigmentosus-inversus. Actas Dermosifiliogr 100: 602605. [Crossref]

9. Kim BS, Park KD, Chi SG, et al. (2008) Two cases of lichen planus pigmentosusinversus arising from lichen planus -inversus. Ann Dermatol 20: 254-6. 
Ghorpade A (2015) Lichen planus pigmentosus-inversus with lesions on labia majora in an Indian lady

10. Kim BS, Aum JA, Kim HS, Kim SJ, Kim MB, et al. (2008) Coexistence of classic lichen planus and lichen planus pigmentosus-inversus: resistant to both tacrolimus and clobetasol propionate ointments. J Eur Acad Dermatol Venereol 22: 106-107. [Crossref]
11. Kashima A, Tajiri A, Yamashita A, Asada Y, Setoyama M (2007) Two Japanese cases of lichen planus pigmentosus-inversus. Int J Dermatol 46: 740-742. [Crossref]

12. Ohshima N, Shirai A, Saito I, Asahina A (2012) Lichen planus pigmentosus-inversus occurring extensively in multiple intertriginous areas. J Dermatol 39: 412-414. [Crossref]

Copyright: (C2015 Ghorpade A. This is an open-access article distributed under the terms of the Creative Commons Attribution License, which permits unrestricted use, distribution, and reproduction in any medium, provided the original author and source are credited. 